\title{
Restriction Site Polymorphism of Ribosomal Ribonucleic Acid Gene Sets in Members of the Genus Bacillus
}

\author{
PAUL GOTTLIEB $†$ AND RIVKA RUDNER* \\ Department of Biological Sciences, Hunter College of the City University of New York, New York, New York 10021
}

\begin{abstract}
Hybridization of cloned ribosomal sequences to EcoRI-restricted genomic deoxyribonucleic acids of eight species and strains of the genus Bacillus produced multiband patterns consistent with the presence of 9 to 11 operons per genome. The basic structure of the repeating ribosomal gene set is highly conserved with the exception of one internal EcoRI site located near the abutment region between the $16 \mathrm{~S}$ and $23 \mathrm{~S}$ ribosomal ribonucleic acid determinants. In each of the Bacillus species studied, there are two abutment regions that differ in size by 0.2 kilobase; the larger region contains genes for isoleucine and alanine transfer ribonucleic acids at one-third the proportion of the smaller region. The occurrence of the EcoRI site in strains of Bacillus subtilis and Bacillus licheniformis gave rise upon cleavage to 1.2- and 1.4-kilobase abutment families. The absence of the EcoRI site in Bacillus globigii, Bacillus pumilus, and Bacillus amyloliquefaciens resulted in the emergence of 1.9- and 2.1-kilobase abutment families. Mixtures of the two types of families were not found in the Bacillus genomes studied.
\end{abstract}

Taxonomic relationships among various species of Bacillus have been studied by deoxyribonucleic acid (DNA)-DNA hybridization and by testing the transformability of auxotrophic and antibiotic resistance genetic markers (10, 21 ). We analyzed the degree of conservation and variation within ribosomal operons of members of the genus Bacillus by following the distribution of internal restriction sites in chromosome digests. The number and physical map of ribosomal ribonucleic acid (rRNA) gene sets in the genome of Bacillus subtilis strain $168 \mathrm{M}$ have been reported by workers from several laboratories $(9,15,25 ; \mathrm{K}$. Bott, G. C. Stewart, and A. G. Anderson, in Syntro Conference on Genetics and Biotechnology of Bacilli, in press). There are 10 rRNA gene sets; each set comprises $16 \mathrm{~S}, 23 \mathrm{~S}$, and $5 \mathrm{~S}$ rRNA determinants, in that order, and two or three also contain genes for isoleucine and alanine transfer ribonucleic acids (tRNA ${ }^{\text {Ile }}$ and tRNA ${ }^{\text {Ala }}$ ) (9). Unlike the situation in Escherichia coli, in which seven rRNA genes are scattered around the map (14), there is a unique clustering of the 10 gene sets in three groups in $B$. subtilis. The major cluster, which is composed of six or seven rRNA genes, is found in the chromosome segment delineated by purA and purB (Bott et al., in press; Rudner et al., unpublished data). Six gene sets have been mapped, $r r n O$ and $r r n A$ at the replication origin $(15,28)$, the closely situated repeats $(r r n I, r r n H$, and $r r n G$ ) near the attachment site of SPO2 (Bott et al., in press), and at least one ( $r r n E$ ) between $d^{-} l^{-}$and purB (Rudner et al., unpublished data). The minor clusters containing three or four of the rRNA cistrons are located in the late replicating portion of the Bacillus genome. Operons $r r n B$ and $r r n C$ have been mapped in the region between $t h r-5$ and aroG (Bott et al., in press). At least one or two cistrons are believed to be located at the ilvBC-leu region (3, 23; P. Gottlieb, G. LaFauci, and R. Rudner, Gene, in press).

The basic physical map which is homologous in all gene sets of $B$. subtilis consists of three internal EcoRI and SmaI sites, two PstI sites, and single BamHI and HindIII sites (Fig. 1) $(9,25)$. The only restriction site which has been

\footnotetext{
* Corresponding author.

$\dagger$ Present address: Public Health Research Institute, New York, NY 10016
}

found to be variable is the HindIII site distal to the 5S rRNA determinant (Fig. 1) (25). Chromosomal patterns after restriction with EcoRI and $B a m \mathrm{HI}$ have been used to calculate the number of gene sets in $B$. subtilis $168 \mathrm{M}(15,25)$. The sizes of the various restriction fragments carrying ribosomal sequences vary considerably, indicating extensive heterogeneity in the inter-operon "spacer." To date, only one case of intragenic size heterogeneity has been reported, one which arises from the abutment region between the $3^{\prime}$ terminus of $16 \mathrm{~S}$ rRNA and the 5 terminus of $23 \mathrm{~S}$ rRNA. There are two EcoRI-generated abutment fragments, measuring 1.1 and 1.3 kilobases $(\mathrm{kb})$ according to Stewart et al. (25) or 1.2 and $1.4 \mathrm{~kb}$ according to our determinations and those of Loughney et al. (9). The larger spacer includes the genes for both tRNA ${ }^{\text {Ile }}$ and tRNA Ala (9). We describe in this paper divergence among the Bacillus species involving sequences in the spacer region between the segment that transcribes the mature $16 \mathrm{~S}$ and the $23 \mathrm{~S}$ ribonucleic acid species.

\section{MATERIALS AND METHODS}

Bacterial strains and plasmids. The strains and plasmids used in this study are listed in Table 1 . The plasmids containing ribosomal insertions were gifts from $\mathrm{K}$. Bott and were amplified in Escherichia coli strain HB101 (pro leu thi lacY hsdR endA recA rpsL20 ara-14 galK2 xyl-5 mtl-1 supE44). Figure 1 shows the sequences of genes coding for rRNA (rDNA) which were inserted into the plasmids used in this study. The cloned fragments originated as follows: (i) p21C4 contains a sheared $0.3-\mathrm{kb}$ fragment around the EcoRI site in the $16 \mathrm{~S}$ determinant cloned by adenine-thymine tailing into plasmid pMB9 (7); (ii) pBC194 contains a 1.1-kb EcoRI fragment with the abutment region of the $16 \mathrm{~S}$ and $23 \mathrm{~S} \mathrm{rDNAs}$ and was subcloned from plasmid p14B1 into the EcoRI site of plasmid pBR322 (25); (iii) p12E2 contains a $6.3-\mathrm{kb}$ BamHIgenerated insertion with homology to $23 \mathrm{~S}$ and $5 \mathrm{~S}$ rDNAs and the 3.5-kb spacer DNA of the rrnA operons (28) cloned into plasmid pBR313 by Zuber and Steinberg; (iv) pBC279 contains a $2.5-\mathrm{kb}$ EcoRI-generated insertion with homology to 23S and 5S rDNAs cloned into plasmid pBR313 by Zuber and Steinberg; and (v) pMS102-B7 contains a $5.7-\mathrm{kb}$ Bam HI insertion which originated from $r r n O(15)$ containing all of 


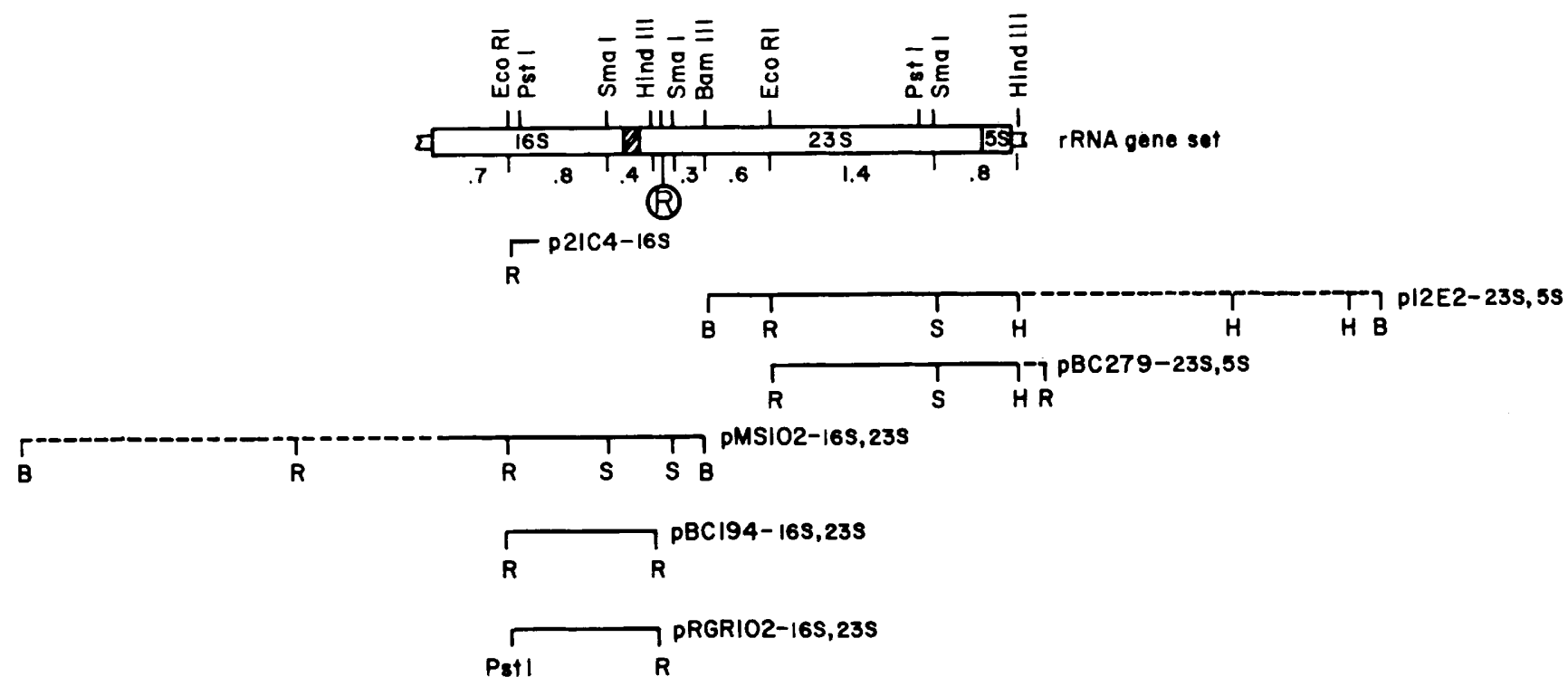

FIG. 1. Generalized restriction map of $B$. subtilis rRNA gene sets as proposed by Stewart et al. (25). The six rRNA fragments from $B$. subtilis inserted into plasmids are represented by solid lines; the dashed lines represent $B$. subtilis DNA sequences which carry no homology to rRNA. B, BamHI; H, HindIII; S, SmaI; R, EcoRI. The internal EcoRI site marked with a circled R is variable in other Bacillus species. The cross-hatched area defines the spacer or abutment region between $16 \mathrm{~S}$ and $23 \mathrm{~S}$ rRNA determinants. Sizes are given in kilobases.

the $16 \mathrm{~S}$ rDNA and one-third of the 23S rDNA cloned into bifunctional plasmid pMS102 (20).

Chromosomal and plasmid DNA isolation and restriction patterns. Bacillus DNAs were prepared from cells grown in VY medium ( $25 \mathrm{~g}$ of veal infusion broth [Difco Laboratories], $5 \mathrm{~g}$ of yeast extract [Difco], and 1,000 $\mathrm{ml}$ of water) and were purified by a modification (19) of the procedure of Marmur (13). Plasmid DNA was purified from $500-\mathrm{ml} \mathrm{cul-}$ tures of Escherichia coli cells grown in LB broth supplemented with either $100 \mu \mathrm{g}$ of ampicillin per ml or $15 \mu \mathrm{g}$ of tetracycline per $\mathrm{ml}$, essentially by the procedure of Tanaka and Weisblum (27). Chromosomal DNA (5 to $10 \mu \mathrm{g}$ ) was digested with restriction endonucleases EcoRI, HindIII, SmaI, PstI, and BamHI ( $3 \mathrm{U}$ of enzyme per $\mu \mathrm{g}$ of DNA for $12 \mathrm{~h}$ at $37^{\circ} \mathrm{C}$ ) by using the conditions for digestion recommended by the supplier (New England BioLabs). DNA fragments were electrophoretically resolved in $0.75 \%$ agarose gels, stained with ethidium bromide, and transferred to nitrocellulose filters for hybridization (24).

Preparation of hybridization probes and densitometry. rRNA for use as a probe was isolated from $B$. subtilis $168 \mathrm{~T}$ grown in VY medium and purified by the method of Margulies et al. (12); 5S, 16S, and 23S rRNA species were prepared in low-melting-point agarose (Bethesda Research Laboratories), and the rRNAs were $5^{\prime}$ end labeled with $[\gamma$ ${ }^{32} \mathrm{P}$ ladenosine triphosphate and $\mathrm{T} 4$ polynucleotide kinase by the method of Maizels (11). Alternatively, cloned rDNA and leu probes were prepared by nick translation with $[\alpha-$ $\left.{ }^{32} \mathrm{P}\right]$ adenosine triphosphate and $\left[\alpha{ }^{32} \mathrm{P}\right]$ cytidine triphosphate (18). The labeled DNA was freed from low-molecular-weight material by passage through a Sephadex G-50 column (Pharmacia Fine Chemicals, Inc.). DNA was routinely labeled to a specific activity of $0.5 \times 10^{8}$ to $2 \times 10^{8} \mathrm{cpm} / \mu \mathrm{g}$. Filter hybridization was performed by using the conditions of Ostapchuk et al. (16). The sizes of the bands obtained by autoradiography were determined by reference to six lambda bands and were calculated from the relationship described by Bearden (2). Some autoradiogram films were scanned at $580 \mathrm{~nm}$ with a Gilford automatic spectrophotometer
TABLE 1. List of strains and plasmids used in this study

\begin{tabular}{|c|c|c|}
\hline Strain or plassmid & $\begin{array}{l}\text { Genotype or } \\
\text { phenotype }^{a}\end{array}$ & Source \\
\hline \multicolumn{3}{|l|}{ Bacterial strains } \\
\hline B. globigii RUB562 & Prototroph & C. Tackney \\
\hline B. pumilus RUB502 & $\begin{array}{l}\text { bio } \operatorname{Rif}^{r} \mathrm{Sm}^{\mathrm{r}} \\
\mathrm{Er}^{\mathrm{r}}\end{array}$ & A. Garro \\
\hline B. licheniformis FDO1 & $S m^{r}$ & D. Dubnau \\
\hline $\begin{array}{l}\text { B. licheniformis ACTC } \\
8480\end{array}$ & $\mathrm{Sm}^{\mathrm{r}}$ & A. Garro \\
\hline B. amyloliquefaciens $\mathrm{H}$ & Prototroph & A. Garro \\
\hline B. subtilis W23 & $\begin{array}{l}\text { Prototroph } \\
\mathrm{SM}^{\mathrm{r}} \mathrm{Er}^{\mathrm{r}} \mathrm{Mic}^{\mathrm{r}}\end{array}$ & D. Dubnau \\
\hline B. subtilis NCTC 3610 & Prototroph & A. Sonenshein \\
\hline B. subtilis $168 \mathrm{~T}$ & $\operatorname{trp} C 2$ & K. Bott \\
\hline B. subtilis 166 & $\operatorname{trpE26}$ & $\begin{array}{l}\text { Bacillus Genetic } \\
\text { Stock Center }\end{array}$ \\
\hline B. stearothermophilus 2184 & $\mathrm{Sm}^{\mathrm{r}}$ & M. S. Friedman \\
\hline \multicolumn{3}{|l|}{ Recombinant plasmids $^{b}$} \\
\hline $\mathrm{p} 21 \mathrm{C} 4$ & $16 \mathrm{~S}$ rRNA, $\mathrm{Tc}^{\mathrm{r}}$ & K. Bott \\
\hline pBC194 & $\begin{array}{l}\text { 16S-23S rRNA, } \\
\mathrm{Am}^{\mathrm{r}} \mathrm{Tc}^{\mathrm{r}}\end{array}$ & K. Bott \\
\hline $\mathrm{pBC} 279$ & $\begin{array}{l}\text { 23S-5S rRNA, } \\
\mathrm{Am}^{\mathrm{r}}\end{array}$ & K. Bott \\
\hline p12E2 & $\begin{array}{l}\text { 23S-5S rRNA, } \\
\mathrm{Am}^{\mathrm{r}}\end{array}$ & K. Bott \\
\hline pMS102-B7 & $\begin{array}{l}\text { 16S-23S rRNA, } \\
\mathrm{Am}^{\mathrm{r}} \mathrm{Km}^{\mathrm{r}}\end{array}$ & K. Bott \\
\hline pRGR102 & $\begin{array}{l}\text { 16S-23S rRNA, } \\
\mathrm{Tc}^{\mathrm{r}} \mathrm{Cm}^{\mathrm{r}}\end{array}$ & $\begin{array}{l}\text { Constructed in } \\
\text { our laboratory }\end{array}$ \\
\hline
\end{tabular}

${ }^{a} \mathrm{Er}^{\mathrm{r}}$, Erythromycin resistance; $\mathrm{Mic}^{\mathrm{r}}$, micrococcin resistance; Rif ${ }^{\mathrm{r}}$, rifampin resistance; $\mathrm{Sm}^{\mathrm{r}}$, streptomycin resistance; $\mathrm{Tc}^{\mathrm{r}}$, tetracycline resistance; $\mathrm{Am}^{r}$, ampicillin resistance; $\mathrm{Km}^{r}$, kanamycin resistance; $\mathrm{Cm}^{r}$, chloramphenicol resistance.

${ }^{b}$ See Fig. 1 . The rDNA sequences were from $B$. subtilis 168 cloned in Escherichia coli plasmids. Plasmids pMS102 (20) and pJH101 (4) are hybrids containing, in addition to $\mathrm{pBR} 322$, pUB110- $\mathrm{Km}^{\mathrm{r}}$ and $\mathrm{pC} 194-\mathrm{Cm}^{r}$, respectively. 
equipped with a model 6051 recorder. The relative areas of the peaks were determined by using a planometer (Noris Instruments).

\section{RESULTS}

Chromosomal patterns of rRNA homology in the genus Bacillus. Complete restriction of Bacillus DNAs with EcoRI, when they were probed with either $23 \mathrm{~S}$ and $5 \mathrm{~S}$ rRNAs or plasmids containing these sequences (pBC279 and p12E2), consistently produced 9 to 11 homologs on Southern blots. Figure 2 shows a composite of four autoradiograms obtained with EcoRI digests of Bacillus DNAs. Table 2 summarizes the molecular sizes and numbers of chromosomal restriction fragments which hybridized to the various probes found in each of the eight members of the genus Bacillus studied. As shown in Fig. 2, the multiple-band patterns were highly intense, indicating, as expected, that ribosomal sequences are extremely homologous in members of the genus Bacillus compared with other Bacillus sequences, such as the aromatic amino acid cluster (26) or the thrA gene (Rudner et al., unpublished data), which gave rise to hybrid bands of relatively low intensities. Similarly, other enzymes (data not shown), such as HindIII, BamHI, SmaI, and PstI, revealed that the probes hybridized with equal intensity to all Bacillus DNAs. The different multiple-band hybridization patterns with respect to homolog size clearly indicate variation not in the rDNA sequences but in the spacer regions. The lower bands resulted from multiple restriction sites internal to the repeating gene set (see below) (Table 3 ). The upper bands arose from one restriction site within the gene set and a second site beyond it in the intergenic spacer region, where evolutionary variation has produced fragments of different sizes.

The multiple-band patterns obtained were unique for each of the species and were highly reproducible between individual strains when data were available. For $B$. subtilis, many derivatives of strains $168 \mathrm{M}$ and NCTC 3610 were analyzed; only two are shown in Table 2 and Fig. 2 , in which the band patterns are identical. Not counting the last three fragments, both $5 \mathrm{~S}$ and $23 \mathrm{~S}$ rRNAs or the cloned rDNA hybridized to nine distinguishable fragments in the EcoRI digests of genomic strain 168M and NCTC 3610 DNAs (Fig. 2 and Table 2). In each digest, at least one hybrid band appeared to be much darker than the others, and scanning of the autoradiogram revealed the presence of two comigrating rDNA homologs (see below). Thus, we agree with previous workers that there are at least 9 , and probably 10 , rRNA gene sets in $B$. subtilis strains $168 \mathrm{M}$ and NCTC $3610(9,25)$. Transformable $B$. subtilis strains $168 \mathrm{M}$ and NCTC 3610 had identical band sizes but shared less homology with strain W23. Similarly, the two Bacillus licheniformis strains studied showed close homology except for certain variations (namely, loss of a 6.5-kb hybrid band and a concomitant increase in size of a second band from 9.0 to $9.8 \mathrm{~kb}$ in strain ACTC 8480) (Table 2). Other variations are discussed below.

Number of $r r n$ operons in the genus Bacillus, as determined by densitometry. Stewart et al. (25) determined from EcoRI restriction patterns that $B$. subtilis 168 has 10 rRNA gene sets per chromosome. This determination was made by counting 23S rRNA homologs observed on Southern blots. This approach is limited by the fortuitous migration of different fragments of the same molecular weight. Southern blots of Bacillus chromosomal digests probed with p12E2$23 \mathrm{~S}, 5 \mathrm{~S}$ labeled DNA or $23 \mathrm{~S}$ rRNA were subjected to densitometry measurements. EcoRI patterns were chosen because the appearance of the internal small fragments clearly indicated that complete restriction had taken place and because the relative proportion of minimal intervals of gene sets that contained tRNA sequences could be calculated (see below). Finally, the intensity of each homolog band was independent of its molecular weight since all bands carried about $2.2 \mathrm{~kb}$ of $23 \mathrm{~S}$ and $5 \mathrm{~S}$ sequences from the central EcoRI site and rightward (Fig. 1). A densitometry tracing of an autoradiogram is shown in Fig. 3. The area of the smallest peak on each scan was designated as 1 and was used to estimate the multiplicity of the other bands. The sum of all band multiplicities provided the estimated total number of rRNA gene sets per genome. All of the Bacillus species appeared to have 9 to 11 gene sets (Table 3). As mentioned above, $B$. licheniformis strain ACTC 8480 was estimated to have 9 or 10 operons, whereas strain FDO1 produced a $6.5-\mathrm{kb}$ band in addition to the $6.0-\mathrm{kb}$ band (Table 2). Therefore, we concluded that the latter strain may possess 10 or 11 rrn operons.

Polymorphism of the abutment fragments in Bacillus. The spacer or abutment fragments which overlap the 3 ' end of the 16S rRNA sequences and the $5^{\prime}$ end of the $23 \mathrm{~S}$ rRNA sequences were identified by using the specific probes shown in Fig. 1. When EcoRI was used to cut B. subtilis DNA, only p21C4-16S, pBC194-16S,23S, and pMS102-16S,23S and 23S rRNAs hybridized to the 1.2- and 1.4-kb fragments (Fig. 2A and $\mathrm{B}$ ) whereas 5S rRNA and pBC279-23S,5S and p12E223S,5S DNA probes did not hybridize to these fragments (Fig. 2C and D). The 0.9-kb fragment extended from the EcoRI site at the $5^{\prime}$ end of the $23 \mathrm{~S}$ coding sequence to the site near the $23 \mathrm{~S}$ center. Therefore, it could hybridize with the comparable $23 \mathrm{~S}$ determinants provided by plasmid probe p12E2-23S,5S (Fig. 2D). Table 3 shows the sizes of only these internal fragments and the hybridization probes that produced them. The two abutment fragments with similar hybridization patterns (that is, differing in size by $0.2 \mathrm{~kb}$ ) were also obtained when $S m a I$ was used (see below). Our findings, as well as those reported previously $(9,25)$, indicate that there are two families of rRNA gene sets in $B$. subtilis, which differ with respect to the size of the EcoRI fragments bridging the $16 \mathrm{~S}$ and $23 \mathrm{~S}$ rRNA determinants. The intensity of the 1.4-kb band shown in Fig. 2A and B indicates that this fragment, like its $1.2-\mathrm{kb}$ counterpart, exists in multiple copies at a ratio of 3:7, as reported by Stewart et al. (25), and at a similar relative proportion of 0.31 according to our densitometry tracing of the autoradiograms (see below).

Among the five Bacillus species and their strains examined in this study, the same pattern of internal EcoRI fragments was observed in B. subtilis strains NCTC $3610,168 \mathrm{M}$, and W23 and B. licheniformis strain ACTC 8480 (Fig. 2 and Table 3). However, in the case of Bacillus globigii RUB562, Bacillus pumilus RUB502, and Bacillus amyloliquefaciens H, the EcoRI site (Fig. 1, circled R) within the $5^{\prime}$ end of the $23 \mathrm{~S}$ sequence was not present. In these three species, the absence of that EcoRI site resulted in larger abutment fragments $(1.9$ to $2.1 \mathrm{~kb})$ and the loss of the 0.9-kb EcoRI fragment. The p12E2-23S,5S probe revealed the 2.1- and $1.9-\mathrm{kb}$ abutment fragments in the species that lost the EcoRI site (B. globigii, $B$. pumilus, and $B$. amyloliquefaciens), but not in the species that retained the site $(B$. subtilis and $B$. licheniformis) (Fig. 2C). The loss of the internal EcoRI site resulted in extending the size of abutment fragments into the range of the p12E2-23S,5S probe (Fig. 1). Plasmid pBC279$23 \mathrm{~S}, 5 \mathrm{~S}$ contains in its cloned sequence $23 \mathrm{~S}$ rDNA extending only to the central EcoRI site (Fig. 1). As a result, neither the $B$. subtilis strains nor the $B$. licheniformis strains produced 


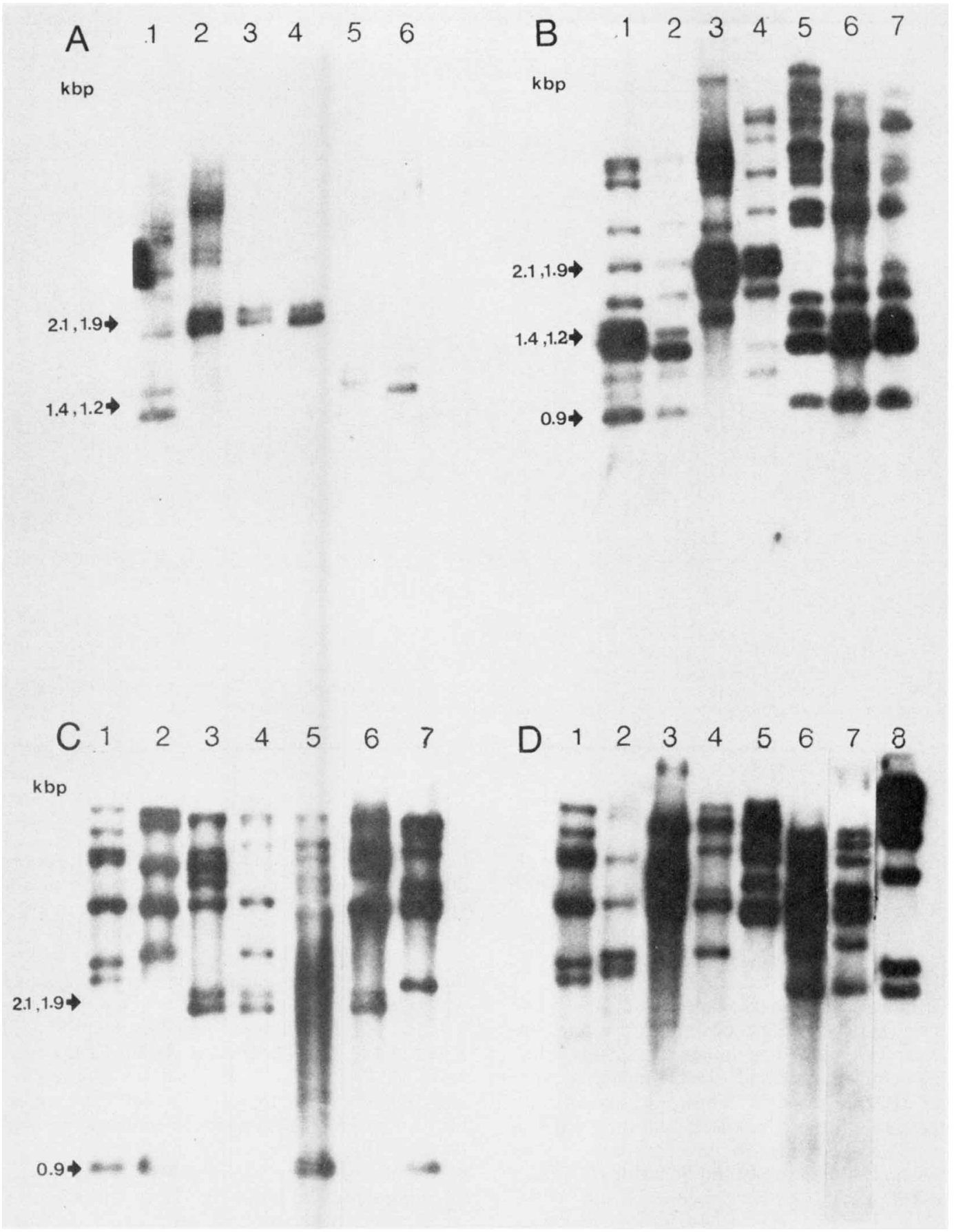

FIG. 2. Hybridization of ${ }^{32}$ P-labeled cloned rDNA to EcoRI digests of Bacillus DNAs after Southern (24) transfer. Each gel lane contained $2 \mu \mathrm{g}$ of restricted chromosomal DNA. The probes were prepared by nick translation, and the resulting specific activities ranged from $0.5 \times$ $10^{8}$ to $2 \times 10^{8} \mathrm{cpm} / \mu \mathrm{g}$ of DNA. The hybridization procedures of Anilionis and Riley (1) involved prehybridization of the filters in a solution containing $40 \%$ formamide, $4 \times \mathrm{SSC}(1 \times \mathrm{SSC}$ is $0.15 \mathrm{M} \mathrm{NaCl}$ plus $0.015 \mathrm{M}$ sodium citrate), $50 \mathrm{mM}$ sodium phosphate $(\mathrm{pH} 6.5), 250 \mu \mathrm{g}$ of sonicated calf thymus DNA per ml, $1 \%$ glycine, and 0.05 volume of Denhardt solution at $42^{\circ} \mathrm{C}$ for at least $1 \mathrm{~h}$. The hybridizations with the ${ }^{32} \mathrm{P}$-labeled probes were for 18 to $22 \mathrm{~h}$ at $37^{\circ} \mathrm{C}$ in a similar solution in the presence of $10 \%$ dextran sulfate at a volume ratio of $40 \mathrm{ml} / \mathrm{cm}^{2}$ of filter with digested chromosomal DNAs. (A) Autoradiogram of EcoRI-digested chromosomal DNAs probed with p21C4-16S. Lane 1, B. subtilis 168T; lane 2, B. amvloliquefaciens $\mathrm{H}$; lane 3, B. globigii RUB562; lane 4, B. pumilus RUB502; lane 5, B. licheniformis FDO1; lane 6, $B$. licheniformis ACTC 8480. (B) Autoradiogram of EcoRI-digested chromosomal DNAs probed with pMS102-16S,23S. Lane 1, $B$. licheniformis FDO1; lane 2, B. licheniformis ACTC 8480; lane 3, B. pumilus RUB502; lane 4, B. globigii RUB562; lane 5, B. subtilis W23; lane 6, B. subtilis 168T; lane 7, B. subtilis NCTC 3610. (C) Autoradiogram of EcoRI-digested chromosomal DNAs probed with p12E2-23S,5S. Lane 1, B. licheniformis FDO1; lane 2, B. licheniformis ACTC 8480; lane 3, B. pumilus RUB502; lane 4, B. globigii RUB B62; lane 5, B. subtilis W23; lane 6, B. amyloliquefaciens H; lane 7, B. subtilis GSY1269 trpE26 ilv C1. (D) Autoradiogram of EcoRI-digested chromosomal DNAs probed with $\mathrm{pBC} 179-23 \mathrm{~S}, 5 \mathrm{~S}$. Lane $1, B$. licheniformis FDO1; lane 2, B. licheniformis ACTC 8480; lane 3, B. pumilus RUB502; lane 4, B. globigii RUB562; lane 5, B. subtilis W23; lane 6, B. subtilis NCTC 3610; lane 7, B. subtilis 168T; lane 8, lambda DNA, HindIII digested. kbp, kilobase pairs. 
TABLE 2. Molecular sizes of EcoRI chromosomal restriction fragments which hybridize to $23 \mathrm{~S}$ and $5 \mathrm{~S}$ rRNAs or plasmids pBC279 and p12E2 in the genus Bacillus

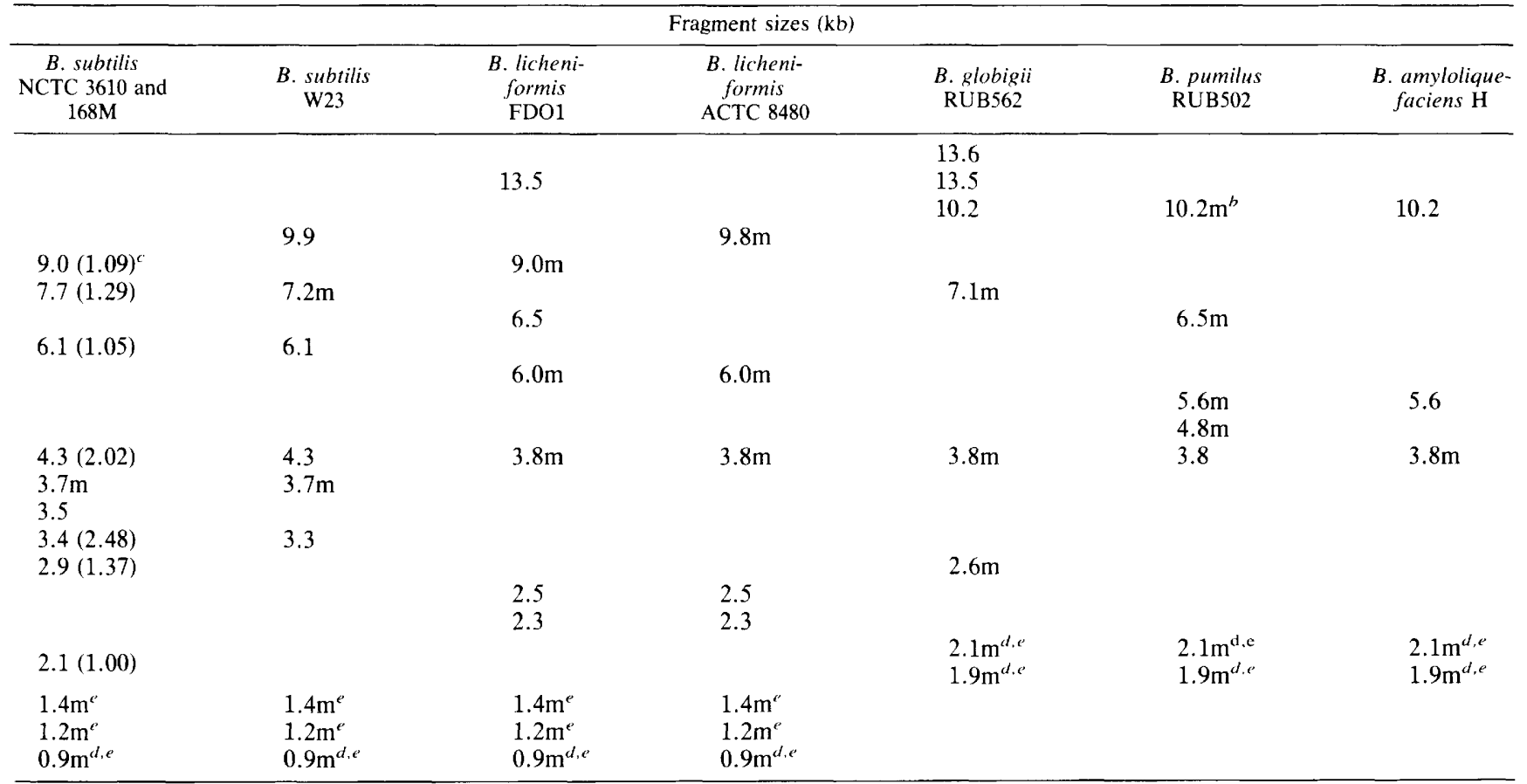

${ }^{a}$ In B. subtilis NCTC 3610 and $168 \mathrm{M}$, B. licheniformis ACTC 8480 , and B. pumilus RUB502 there are 9 or 10 gene sets; in $B$. subtilis W23 and $B$. globigii RUB562 there are 9 gene sets; and in $B$. licheniformis FDO1 and $B$. amyloliquefaciens $\mathrm{H}$ there are 10 or 11 gene sets.

${ }^{b} \mathrm{~m}$, Multiple bands.

The numbers in parentheses are unit areas (see Fig.3). Band multiplicity was calculated from the 1.00-U homolog of the $2.1-\mathrm{kb}$ homology.

${ }^{d}$ Band visible with the p12E2-23S,5S probe.

"Band visible with the 23S rRNA probe.

their abutment region as this probe shares no homology with it (Fig. 1 and 2D). Plasmid pMS102-16S,23S, as well as the end-labeled $23 \mathrm{~S}$ rRNA probe, showed the three internal EcoRI fragments in the first group of Bacillus species, whereas the second group displayed the two large EcoRI pieces (Fig. 2B).

The relative proportions of the two families of rRNA gene sets (those containing tRNA sequences and those not containing tRNA sequences) were determined by densitometry. Figure 4 shows tracings of minimal EcoRI fragments from the two types of rDNA gene sets. The total area of both peaks was computed with the planometer and the ratio was calculated. Type I Bacillus species gave ratios of $1.4-\mathrm{kb}$ bands to $1.2-\mathrm{kb}$ bands of $0.31,0.31$, and 0.28 (for $B$. subtilis strains $168 \mathrm{M}$ and $\mathrm{W} 23$ and $B$. licheniformis strain ACTC 8480 , respectively). However, type II Bacillus species gave ratios of $2.1-\mathrm{kb}$ bands to $1.9-\mathrm{kb}$ bands of 0.34 and 0.42 (for $B$. globigii strain RUB562 and B. pumilus strain RUB502, respectively).

Restriction of chromosomal DNA with restriction enzyme $S m a$ I confirmed the conservation of the SmaI sites (Table 3). The distinct $2.3-\mathrm{kb}$ fragment was present in $B$. subtilis, $B$. globigii, and $B$. pumilus. When the chromosomal digests were probed with pMS102-16S,23S, they consistently gave rise to only two abutment fragments, the $0.5-$ and $0.7-\mathrm{kb}$ fragments (Table 3). The size difference of 180 to 200 base pairs suggests that the abutment region was conserved with respect to size, sequence, and the relative proportions of the larger piece and the smaller piece.

Additional heterogeneity in internal fragment size was observed in two Bacillus strains. One of these was $B$. licheniformis strain FDO1, which produced an extra abutment fragment when it was probed with plasmid pBC194$16 \mathrm{~S}, 23 \mathrm{~S}$ or pMS102-16S,23S. As shown in Fig. 5, a 1.3-kb band was found in addition to the two abutment fragments $(1.2$ and $1.4 \mathrm{~kb})$. The ratio of the $1.4-\mathrm{kb}$ band to the sum of the 1.2- and 1.3-kb bands in strain FDO1 was 0.45 , which was significantly higher than the value of 0.28 found for the 1.4- and 1.2-kb abutment fragments in strain ACTC 8480. As noted above, $B$. licheniformis strain FDO1 has $11 \mathrm{rrn}$ gene sets (Table 2). The additional operon might contain an insertion of a single tRNA in its abutment region, giving rise to the $B$. subtilis DNA probes containing parts of tRNA ${ }^{\text {lle }}$ or tRNA $^{\text {Ala }}(9)$.

A similar situation was observed in the EcoRI digests of $B$. amyloliquefaciens strain $\mathrm{H}$. Here the digests, when they were probed with pBC194, produced a doublet at the position of the 1.9-kb band and two minor bands (Fig. 5). The latter corresponded to the 1.4 - and $1.2-\mathrm{kb}$ bands found in the first group of Bacillus species (Table 3). Finally, Bacillus stearothermophilus strain 2184 gave rise to a single internal EcoRI fragment (1.9 kb) (Fig. 5).

\section{DISCUSSION}

In this paper we present data on the conserved nature of the ribosomal gene sets among Bacillus species. The basic $r r n$ repeating unit is highly conserved, whereas extensive heterogeneity is found in the interoperon spacer regions. In chromosomal restrictions, $B$. subtilis strain NCTC 3610 is identical to strain $168 \mathrm{M}$. In contrast, these two strains differ significantly from prototrophic strain W23, which was once used as a source of donor DNA for transformation. $B$. 
TABLE 3. Molecular sizes of restriction fragments internal to the rRNA gene set in members of the genus Bacillus

\begin{tabular}{|c|c|c|c|c|c|c|c|}
\hline \multirow[b]{2}{*}{ Enzyme } & \multirow[b]{2}{*}{ Strain(s) } & \multicolumn{6}{|c|}{ Fragment sizes $(\mathrm{kb})$ with the following probes: } \\
\hline & & $\begin{array}{c}\text { p21C4-16S or } \\
\text { pBC194-16S,23S }\end{array}$ & $23 \mathrm{~S}$ & $5 \mathrm{~S}$ & $\begin{array}{c}\text { pBC279- } \\
23 \mathrm{~S}, 5 \mathrm{~S}\end{array}$ & $\begin{array}{l}\text { p12E2- } \\
23 \mathrm{~S}, 5 \mathrm{~S}\end{array}$ & $\begin{array}{l}\text { pMS102- } \\
16 S, 23 \mathrm{~S}\end{array}$ \\
\hline \multirow[t]{12}{*}{ EcoRI } & B. subtilis $168 \mathrm{~T}$, NCTC 3610 , and & 1.4 & 1.4 & $\ldots^{a}$ & - & 0.9 & 1.4 \\
\hline & W23 & 1.2 & 1.2 & & & & 1.2 \\
\hline & & & 0.9 & & & & 0.9 \\
\hline & B. licheniformis $\mathrm{FDO} 1$ and $\mathrm{NCTC}$ & 1.4 & 1.4 & $\mathrm{ND}^{b}$ & & 0.9 & 1.4 \\
\hline & $8480^{\circ}$ & 1.2 & 1.2 & & & 0.9 & 1.2 \\
\hline & & & 0.9 & & & & 0.9 \\
\hline & B. globigii RUB562 & 2.1 & 2.1 & - & - & 2.1 & 2.1 \\
\hline & & 1.9 & 1.9 & & & 1.9 & 1.9 \\
\hline & B. pumilus RUB502 & 2.1 & 2.1 & - & - & 2.1 & 2.1 \\
\hline & & 1.9 & 1.9 & & & 1.9 & 1.9 \\
\hline & B. amyloliquefaciens $\mathrm{H}^{d}$ & 2.1 & ND & ND & - & 2.1 & 2.1 \\
\hline & & 1.9 & & & & 1.9 & 1.9 \\
\hline \multirow[t]{9}{*}{ Smal } & B. subtilis $168 \mathrm{~T}$, NCTC 3610 , and & - & 2.3 & - & 2.3 & 2.3 & 2.3 \\
\hline & W23 & & & & & & 0.7 \\
\hline & & & & & & & 0.5 \\
\hline & B. globigii RUB562 & - & 2.3 & - & 2.3 & 2.3 & 2.3 \\
\hline & & & & & & & 0.7 \\
\hline & & & & & & & 0.5 \\
\hline & B. pumilus RUB502 & - & 2.3 & - & 2.3 & 2.3 & 2.3 \\
\hline & & & & & & & 0.7 \\
\hline & & & & & & & 0.5 \\
\hline
\end{tabular}

- Hybrid band not present.

${ }^{b}$ ND. Not determined.

' $B$. licheniformis FDO1 exhibited three hybrid bands $(1.4,1.3$, and $1.2 \mathrm{~kb}$ ) (see Fig. 5).

${ }^{d} B$. amyloliquefaciens $\mathrm{H}$ exhibited two additional faint hybrid bands (1.4 and $1.2 \mathrm{~kb}$ ) (see Fig. 5).

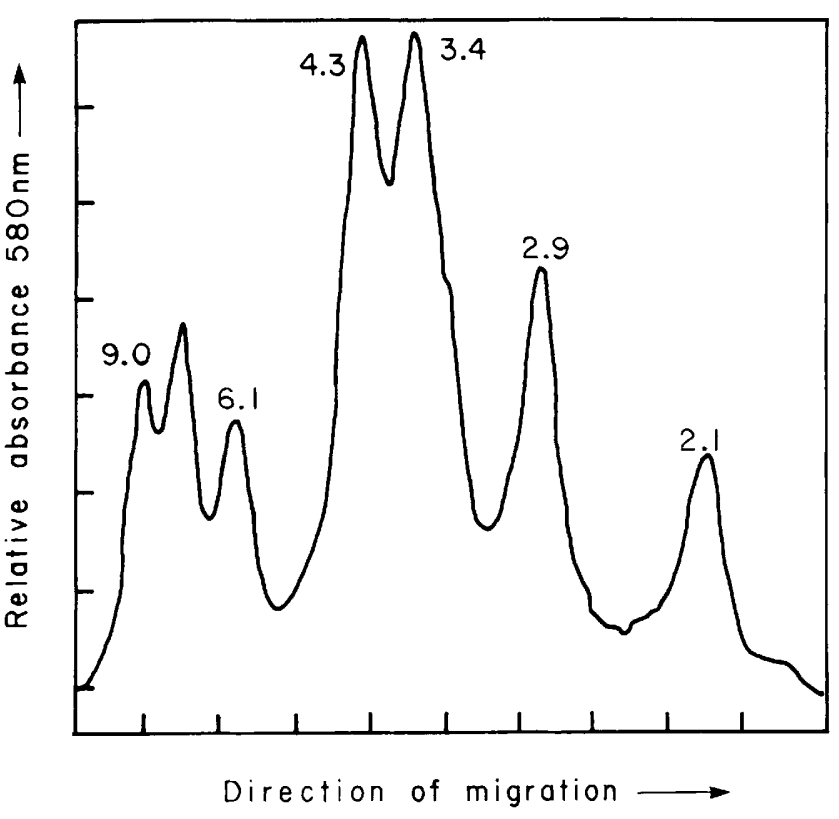

FIG. 3. Densitometry tracing of an autoradiogram of EcoRI 23S rRNA homologs. Chromosomal DNA of $B$. subtilis NCTC 3610 was restricted to completion with endonuclease EcoRI ( $3 \mathrm{U}$ of enzyme per $\mu \mathrm{g}$ of DNA). Then $2 \mu \mathrm{g}$ of the digest was added to each well of a $0.75 \%$ agarose gel. Southern blots were made of these gels and hybridized to ${ }^{32} \mathrm{P}$-labeled $23 \mathrm{~S}$ rRNA (30 to $40 \mathrm{ng}$ of probe per gel subtilis W23 is known to differ from strains NCTC 3610 and $168 \mathrm{M}$ by its phage spectrum, cell wall components, and marker survival after restriction with EcoRI and HindIII (6, 26). Seiki et al. (20) reported DNA homologies between $B$. subtilis $168 \mathrm{M}$ and $\mathrm{W} 23$ of 70 and $67 \%$ in reciprocal hybridizations. Two B. licheniformis strains, strains FDO1 and ACTC 8480 , show a close and expected homology based on the criteria used in this study. Some variation is manifest by an additional $r r n$ homolog which is found in strain FDO1 but is not present in strain ACTC 8480. In addition, one or more rRNA gene sets of strain FDO1 may contain a different $16 \mathrm{~S}, 23 \mathrm{~S}$ abutment region with only one tRNA sequence instead of the usual forms with two or none.

Previous estimates of the levels of homology between the DNA of $B$. subtilis $168 \mathrm{M}$ and the DNAs of $B$. licheniformis FD01, $B$. amyloliquefaciens $\mathrm{H}$, and $B$. pumilus NRRL B-3275 were to 24,11 , and $16 \%$, respectively (10). The levels of DNA homology obtained from hybridiziation of ${ }^{3} \mathrm{H}$ labeled input $B$. subtilis 168 DNA and nitrocellulose diskbound DNAs from 52 test strains of eight species were of 25 ,

lane). The hybridization reaction was for $12 \mathrm{~h}$ under the conditions described by Ostapchuk, et al. (16). The hybridized filter was filmed for $10 \mathrm{~h}$ at room temperature. The chart paper of the densitometer recorder was run at $20 \mathrm{~cm} / \mathrm{min}$, and the autoradiogram lane was scanned at $4 \mathrm{~cm} / \min (580 \mathrm{~nm})$. The numbers over the peaks are molecular sizes (in kilobases). 
13 , and $7 \%$ for B. amyloliquefaciens $\mathrm{F}$, B. licheniformis $(13$ strains), and $B$. pumilus IFO 12110 , respectively (21). Based on their DNA homology index data, Seki et al. divided the genus Bacillus into three groups. One of these groups had a homology index to strain $168 \mathrm{M}$ of more than $70 \%$ and transformed widely dispersed auxotrophic markers. The second group, with a level of DNA homology to strain 168 of 20 to $25 \%$, did not transform auxotrophic markers but did transform antibiotic resistance. The third group had a level of DNA homology to strain 168 of 7 to $15 \%$ and showed some detectable transformation of antibiotic resistance markers (21).

The Bacillus strains examined in this study can be divided

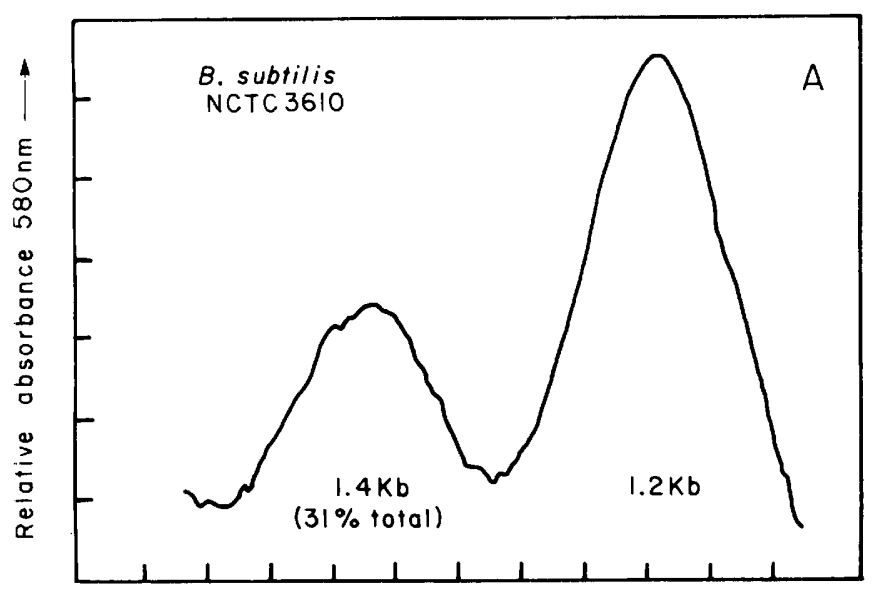

Direction of migration

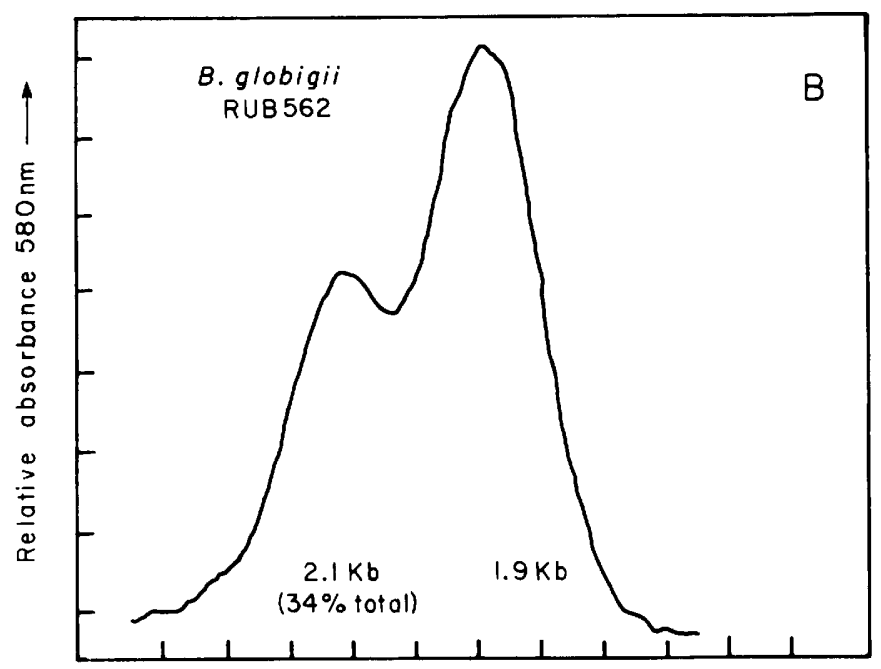

Direction of migration

FIG. 4. Densitometry tracings of autoradiograms of the two types of $16 \mathrm{~S}$ and $23 \mathrm{~S}$ abutment fragments. Chromosomal DNA was restricted with $E c o$ RI as described in the legend to Fig. 3. Hybridization was with ${ }^{32} \mathrm{P}$-end-labeled $23 \mathrm{~S}$ rRNA. The region of the autoradiogram displaying the abutment fragments was scanned at 1 $\mathrm{cm} / \mathrm{min}$, and the chart recorder paper was run at $20 \mathrm{~cm} / \mathrm{min}$. (A) Type I rDNA abutment fragments (1.2 and 1.4 kilobase pairs) with the $23 S$ determinant EcoRI site from B. subtilis NCTC 3610. (B) Type II rDNA abutment fragments (1.9 to 2.1 kilobase pairs) without the $23 \mathrm{~S}$ determinant EcoRI site from $B$. globigii RUB562.

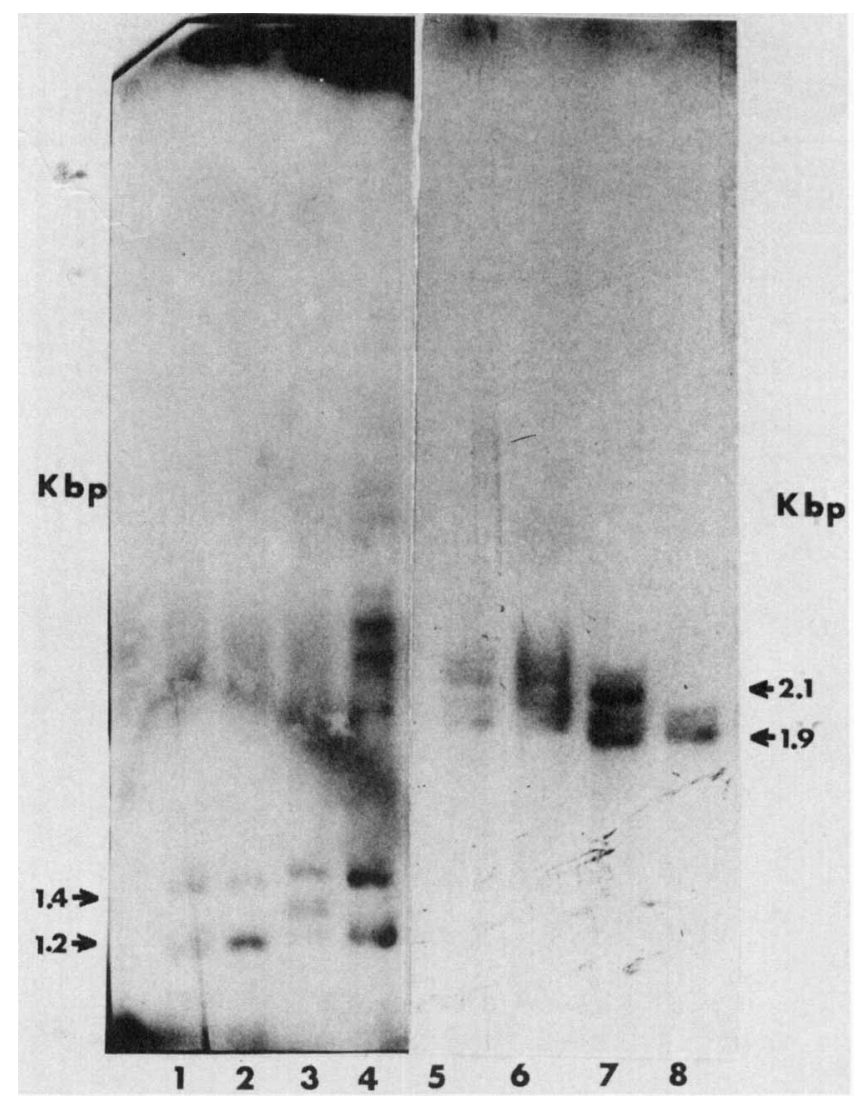

FIG. 5. Autoradiographic localization of the two types of abutment fragments in EcoRI digests of Bacillus DNAs probed with pBC194-16S,23S. For experimental details, see the legend to Fig. 2. Lane $1, B$. subtilis NCTC 3610 ; lane 2, B. subtilis W23; lane $3, B$. licheniformis FDO1; lane 4, B. licheniformis ACTC 8480; lane 5, $B$. globigii RUB562; lane 6, B. pumilus RUB502; lane 7, B. amyloliquefaciens $\mathrm{H}$; lane $8, B$. stearothermophilus 2184 . kbp, kilobase pairs.

into two groups, those with the internal EcoRI site (type 1) and those without this site (type II). Upon digestion with restriction enzymes EcoRI and SmaI, the DNAs of these strains yielded abutment fragments differing in size by precisely $0.2 \mathrm{~kb}$. With the exception of one strain, none of the strains gave rise to a mixture of both types of fragments (namely, a $1.4-\mathrm{kb}$ fragment and a $1.9-\mathrm{kb}$ fragment or a $1.2-\mathrm{kb}$ fragment and a 2.1-kb fragment). In $B$. amyloliquefaciens $\mathrm{H}$ we observed small amounts of the lower bands (1.4 and 1.2 $\mathrm{kb}$ ), yet more than $80 \%$ of the hybrids were the two larger abutment fragments (Fig. 4). Moreover, we predict no variation in the distribution of abutment fragments in Bacillus DNAs digested with restriction enzyme PstI or in a double digest with PstI and HindIII. The sizes expected for the conserved abutment regions are 3.1 and $3.3 \mathrm{~kb}$ for the former enzyme and 0.9 and $1.1 \mathrm{~kb}$ for the codigestion (9). The absence of additional heterogeneity in fragment size strongly suggests that the original loss of that EcoRI site which led to the appearance of the two larger abutment fragments (1.9 and $2.1 \mathrm{~kb}$ ) could have occurred in a proto-Bacillus species before the main rRNA gene amplification. Interoperon spacer variations, genomic rearrangements, and gene duplication evolved later and led to the observed changes in the molecular sizes of the larger rDNA fragments. An evolution- 


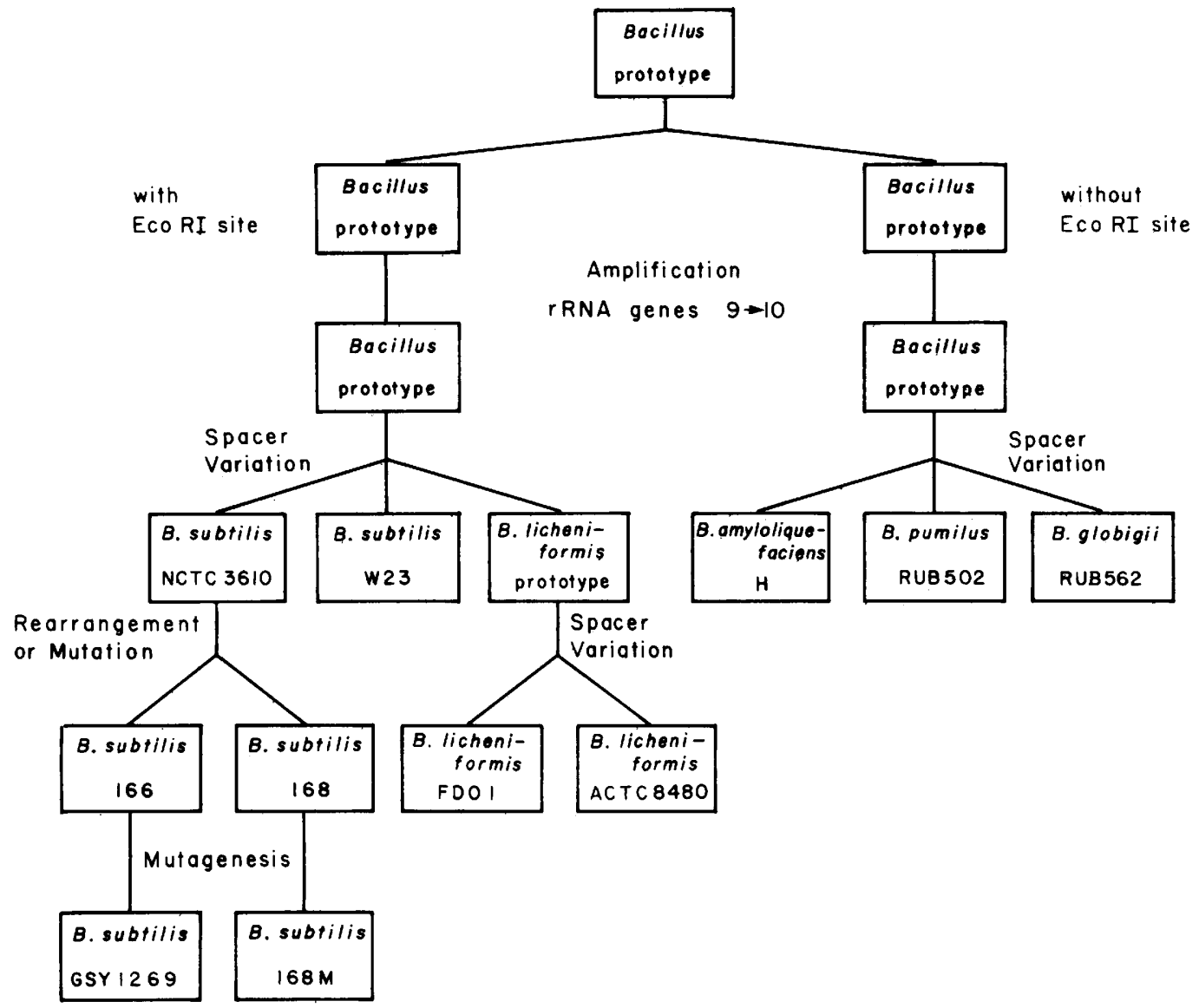

FIG. 6. Dendrogram analysis of the relationships among five species of Bacillus and their strains. The bacteria examined in this study were divided into two lines of descent based upon the structures of their rRNA gene sets. Type I Bacillus species have rRNA genes possessing the 5' $23 \mathrm{~S}$ sequence EcoRI site (see Fig. 1), and the type II species have rRNA genes without the EcoRI site.

ary dendrogram which illustrates a proposed derivation and relationship among these Bacillus species is shown in Fig. 6.

Alternatively, horizontal evolution via amplification of one variant $r r n$ cistron could also produce this result. Unequal crossing-over can fix a given sequence type within a population of heterogeneous sequences (22). According to this model, an entire gene cluster is replaced by a different type of gene copy, an event that would occur after $r r n$ gene multiplication. Smith (22) has presented a model of "crossover fixation," which could effectively propagate a variant sequence with the elimination of another. This event also depends upon the occurrence of unequal crossing-over among tandem repeats of genes in a tandem array of a fixed size; through such unequal crossing-over the original genes are eventually eliminated and replaced by others. Such a model allows the fixation for type I or type II rDNA sequences to occur at any time in evolution and clearly explains how a gene variant originally in the minority can ultimately become the predominant or only type. In fact, we describe in another study mutants of $B$. subtilis displaying an rDNA deletion or duplication as evidence that such a mechanism might be occurring (Gottlieb et al., in press). The addition, alteration, or replacement of rDNA in transformants of these mutants lends further credence to the dynamic nature of the rDNA repeats (Gottlieb et al., in press; Rudner et al., unpublished data).

In summary, the physical organization of an rRNA gene set in the genus Bacillus is unique in size, as shown by the positions of restriction site sequences which remained unchanged. It is intriguing that even the length of the spacer regions between $16 \mathrm{~S}$ and $23 \mathrm{~S}$ rRNA coding sequences, which potentially could have varied, are highly conserved. Only two sizes have evolved, differing by $0.2 \mathrm{~kb}$; the larger abutment fragment contains the tRNA ${ }^{\text {lle }}$ and tRNA Ala genes (9). Similar tRNA sequences are located in the analogous region of the Escherichia coli rRNA operons (29), as well as in chloroplast rDNAs of Euglena gracilis (5), and Zea mays (8). This strong sequence homology between spacer regions of gram-positive bacteria and gram-negative bacteria, as well as the chloroplasts of eucaryotes, indicates functional significance and structural constraints. It is tempting to speculate that the spacer regions, particularly those with the tRNA genes, can form secondary structures which constitute part of a signal structure necessary for proper processing of the common precursors. On the other hand, the intergenic spacer region between adjacent rRNA operons seems to have suffered a higher genetic drift rate in the genus Bacillus.

\section{ACKNOWLEDGMENTS}

We thank the following students for assisting in some of these studies: D. Nembhard, R. Sepulveda, and W. Williamson.

This work was supported by Public Health Service grant GM16059 from the National Institute of General Medical Sciences, by City University of New York Faculty Research Awards 14024 and 663152, and by Public Health Service Minority Biomedical 
Research Support Grant RRO81776-04 from the National Institutes of Health.

\section{ADDENDUM IN PROOF}

K. F. Bott (University of North Carolina Medical School, Chapel Hill) has made available to us the complete sequence of the B. subtilis $r r n B$ operon which confirms the size of the abutment EcoRI fragments as 1.1 or $1.3 \mathrm{~kb}$.

\section{LITERATURE CITED}

1. Anilionis, A., and M. Riley. 1980. Conservation and variation of nucleotide sequences within related bacterial genomes: Escherichia coli strains. J. Bacteriol. 143:355-365.

2. Bearden, J. 1979. Electrophoretic mobility of high molecular weight double strand DNA on agarose gels. Gene 6:221-234.

3. Chilton, M. D., and B. J. McCarthy. 1969. Genetic and base sequence homologies in bacilli. Genetics 62:697-710.

4. Ferrari, F. A., A. Nguyen, D. Lang, and J. A. Hoch. 1983. Construction and properties of an integrable plasmid for Bacillus subtilis. J. Bacteriol. 154:1513-1515.

5. Graf, L., H. Kussel, and E. Stutz. 1980. Sequencing of 16S-23S spacer in a ribosomal RNA operon of Euglena gracilis chloroplast DNA reveals two tRNA genes. Nature (London) 286:908-910.

6. Hemphill, H., and H. R. Whiteley. 1975. Bacteriophages of Bacillus subtilis. Bacteriol. Rev. 39:257-315.

7. Hutchison, K. W., and H. O. Halvorson. 1980. Cloning of randomly sheared DNA fragments from a $\phi 105$ lysogen of Bacillus subtilis: identification of prophage-containing clones. Gene 8:267-278

8. Koch, W., K. Edwards, and H. Kussel. 1981. Sequencing of the 16S-23S spacer in a ribosomal RNA operon of Zea mays chloroplast DNA reveals two split tRNA genes. Cell 25: 203-213.

9. Loughney, K., E. Lund, and J. E. Dahlberg. 1982. tRNA genes are found between the $16 \mathrm{~S}$ and 23S rRNA in Bacillus subtilis. Nucleic Acids Res. 10:1607-1624.

10. Lovett, P. S., and F. E. Young. 1969. Identification of Bacillus subtilis NRRL B-3275 as a strain of Bacillus pumilus. J. Bacteriol. 100:658-661.

11. Maizels, N. 1977. RNA labeling mediated by T4 polynucleotide kinase, p. 247-251. In G. Wulcox, J. Abelson, and C. F. Fox (ed.), ICN-UCLA Symposium on Molecular and Cellular Biology, vol. 8. Academic Press, Inc., New York.

12. Marguiles, L., V. Remeza, and R. Rudner. 1971. Asymmetric template function of microbial deoxyribonucleic acids: transcription of messenger ribonucleic acid. J. Bacteriol. 107: 610-617.

13. Marmur, J. 1961. A procedure for the isolation of DNA from microorganisms. J. Mol. Biol. 3:208-218.

14. Nomura, M., and L. E. Post. 1980. Organization of ribosomal genes and regulation of their expression in Escherichia coli, p.
671-691. In G. Chambliss, G. R. Craven, K. Davis, L. Cahan, and M. Nomura (ed.), Ribosomes: structure, function and genetics. University Park Press, Baltimore.

15. Ogasawara, N., M. Seiki, and H. Yoshikawa. 1983. Replication origin region of Bacillus subtilis contains two rRNA operons. J. Bacteriol. 154:50-57.

16. Ostapchuk, P., A. Anilionis, and M. Riley, 1980. Conserved genes in enteric bacteria are not identical. Mol. Gen. Genet. 180:475-477.

17. Pace, N., M. Pato, J. McKibbin, and C. Radcliffe. 1973. Precursors of 5S ribosomal RNA in Bacillus subtilis. J. Mol. Biol. 75:475-477.

18. Rigby, P. W. J., M. Dieckmann, C. Rhodes, and P. Berg. 1977. Labeling deoxyribonucleic acid to high specific activity in vitro by nick translation with DNA polymerase. 1. J. Mol. Biol. 113:237-251.

19. Rudner, R., H. Lin, S. Hoffman, and E. Chargaff. 1967. Studies on the loss and restoration of transforming activity of the DNA of B. subtilis. Biochim. Biophys. Acta 144:199-219.

20. Seiki, M., N. Ogasawara, and H. Yoshikawa. 1981. Structure and function of the region of the replication origin of the $B$. subtilis chromosome. I. Isolation and characterization of plasmids containing the origin region. Mol. Gen. Genet. 183:220-226.

21. Seki, T., T. Oshima, and Y. Oshima. 1975. Taxonomic study of Bacillus by deoxyribonucleic acid-deoxyribonucleic acid hybridization and interspecific transformation. Int. J. Syst. Bacteriol. 25:258-270.

22. Smith, B. 1974. Unequal crossover and the evolution of multigene families. Cold Spring Harbor Symp. Quant. Biol. 38:504-513.

23. Smith, I., D. Dubnau, P. Morell, and J. Marmur. 1968. Chromosomal location of DNA base sequences complementary to transfer RNA and to 5S, 16S and 23S ribosomal RNA in Bacillus subtilis. J. Mol. Biol. 33:123-140.

24. Southern, E. 1975. Detection of specific sequences among DNA fragments separated by gel electrophoresis. J. Mol. Biol. 98:503-517.

25. Stewart, G., F. Wilson, and K. Bott. 1982. Detailed physical mapping of the ribosomal RNA genes of Bacillus subtilis. Gene 19:153-162.

26. Tackney, C., and R. Rudner. 1981. Genetic and nucleotide sequence homologies in Bacillus genomes. Mol. Gen. Genet. 183:234-237.

27. Tanaka, T., and B. Weisblum. 1975. Construction of a colicin E1-R factor composite plasmid in vitro: means for amplification of deoxyribonucleic acid. J. Bacteriol. 121:354-362.

28. Wilson, F., J. Hoch, and K. Bott. 1981. Genetic mapping of a linked cluster of ribosomal ribonucleic acid genes in Bacillus subtilis. J. Bacteriol. 148:624-628.

29. Young, R., R. Bram, and J. Steitz. 1980. rRNA and tRNA processing signals in the rRNA operons of Escherichia coli, $\mathrm{p}$ 99-106. In D. Sull, J. A. Abelson, and R. R. Schimmel (ed.), Transfer RNA: biological aspects. Cold Spring Harbor Laboratory Press, Cold Spring Harbor, N.Y. 